Research Article

\title{
Awareness and treatment seeking behaviour of malaria in selected endemic and non-endemic rural areas of Kanyakumari district, Tamilnadu, India
}

\author{
SureshBalan Kumaraswamy Uma ${ }^{1}$, Madhumitha Manohar ${ }^{2}$, Gopal Muthukrishnan $^{3}$, Kiruba \\ Jebamony ${ }^{2}$, Shankar Radhakrishnan ${ }^{4}$.
}

\begin{abstract}
${ }^{1}$ Department of Community Medicine, Government Thoothukudi Medical College, Tamilnadu, India
${ }^{2}$ Department of Community Medicine, Government Medical College, Kanyakumari, Tamilnadu, India

${ }^{3}$ Department of Community Medicine, Government Medical College, Sivaganga, Tamilnadu, India

${ }^{4}$ Department of Community Medicine, VMKVMCH, Salem, Tamilnadu, India
\end{abstract}

Received: 29 January 2016

Accepted: 10 February 2016

\author{
*Correspondence: \\ Dr. Shankar Radhakrishnan, \\ E-mail: shnkr_radhakrishnan@yahoo.com
}

Copyright: () the author(s), publisher and licensee Medip Academy. This is an open-access article distributed under the terms of the Creative Commons Attribution Non-Commercial License, which permits unrestricted non-commercial use, distribution, and reproduction in any medium, provided the original work is properly cited.

\begin{abstract}
Background: Malaria is one of the world's major public health concerns contributing to 243 million clinical cases and around million deaths annually. India reports the highest malaria burden in the South East Asia region. There is evidence that the availability of services alone may not ensure healthy practices, as they could be influenced by socio cultural barriers and inappropriate understanding of the disease etiology. Understanding of community perceptions and practices are crucial to bring down the burden of malaria. The objectives was to assess the awareness of malaria and treatment seeking behavior in an endemic and non-endemic area and to highlight the differences in the perceptions and treatment seeking behavior between the two areas.

Methods: A descriptive study was undertaken in Primary Health Centres of Rajakkamangalamthurai (Endemic) and Chembagaramanputhur (Non endemic) for 2 Months. Patients with fever above the age of 15 years attending the Outpatient department of both the PHCs were chosen as study subjects. 150 patients were included in the study. Responses regarding malaria awareness and treatment seeking behavior were obtained using pre-structured, pre-tested and closed ended questionnaire.

Results: Majority of the study subjects from the endemic area gave a correct response to the questions related to the disease terminology, modes of transmission and the usefulness of indoor residual sprays than the subjects from the non-endemic area and the difference was found to be statistically significant $(\mathrm{P}<.05)$. Most of the patients from the non-endemic areas were not aware about any information regarding malaria. Among the health seeking behaviour majority of the study subjects from the endemic area visits the health centre in less than 3 days after the onset of fever and also undergo a blood smear examination than that of the patients from the non-endemic area and the difference was found to be statistically significant. Majority of the patients from a non-endemic area opted for private hospital for their treatment whereas majority of them from the endemic area received the treatment from a government hospital.

Conclusions: The lack of awareness of malaria in non endemic areas need special attention and the need of health awareness through the health care workers should be enhanced in both the endemic and non-endemic areas.
\end{abstract}

Keywords: Malaria, Endemic area, Non-endemic area, Awareness 


\section{INTRODUCTION}

Despite of great efforts over decades in controlling malaria it still remains a serious public health problem in the tropical and sub-tropical regions, where 350-500 million people are infected with malaria and about two millions die each year. About three million cases of malaria have been reported in South East Asia Region (WHO) each year and in that India accounts for about 60 percent of the total cases. ${ }^{1}$

The human behaviour with regard to their perception on etiology, treatment and prevention of malaria fosters the spread of the disease within the community. People seek medical advice depending on the individual perception of ill health so, fever is still not perceived as a serious symptom. Many community- based studies have proved that knowledge about malaria among general population is still poor and there is no promptness in treatment seeking behaviour among fever cases. People still confuse over symptoms of malaria and its preventive measures. Correct assessment of community attitudes, knowledge and behaviour can assist the reformulation of malaria control strategy and can form the basis of appropriate health education messages. ${ }^{2}$

Government reports had quoted that technical, administrative, financial and logistic problems had led to the resurgence of malaria in India in the 1970s and 1980s, apart from it the other major reasons were the socioeconomic and political situation in the country. ${ }^{3}$ The major setback in implementing the malaria eradiation/control program was that the people's perceptions and their coping strategies were not taken into account while planning. Social issues with the failure of techno centric vertical programs and reemergence of infectious diseases, the relevance of social science researches in malaria have been realized. It has widely acknowledged that an understanding of sociocultural and ecological contexts of malaria transmission is crucial to the success of all efforts to control malaria. ${ }^{4-7}$

Self-treatment, which is widely practiced is another important reason for the increased prevalence of malaria especially in the developing countries. ${ }^{8}$ It is considered an alternative way for those who are unable to afford the cost of health services and they are more likely to start with self treatment at home as this practice yields them to minimize expenditure and suffering in the remote areas where transportation and availability of health services pose a major problem. ${ }^{9}$

In the context of a community based approach the understanding of community perceptions and practices are crucial for the policy makers to embed the disease control interventions into the socio-cultural dimensions of the community for effective adoption of healthy practices. $^{10}$ As evidenced by NVBDCP reports, Kanyakumari district of TamilNadu is endemic for malaria for several decades. Hence this study has been attempted to find out and compare the level of awareness and treatment seeking behavior among the rural residents between the areas coming under the jurisdiction of endemic and non-endemic primary health centres of Kanyakumari district and as of today only very few studies had been conducted in India in assessing the treatment seeking behaviour for malaria. Objective of the study is to assess the awareness of malaria and treatment seeking behavior in an endemic and non endemic area and to highlight the differences in the perceptions and treatment seeking behavior between the two areas.

\section{METHODS}

A cross sectional descriptive study was undertaken in Primary Health Centres of Rajakkamangalamthurai (Endemic) and Chembagaramanputhur (Non endemic) for 2 Months (From $1^{\text {st }}$ August 2015 to $30^{\text {th }}$ September 2015). Patients with fever above the age of 15 years attending the outpatient department of both the PHCs were chosen as study subjects. Non-random type of sampling was followed in selection of the study subjects. A total of 150 patients from each PHC were included for the study. Informed consent was taken and responses regarding malaria awareness and treatment seeking behavior were obtained using pre-structured, pre-tested and closed ended questionnaire. The variables taken for the study include socio-economic and demographic factors, malaria awareness, treatment seeking behavior and prevention and control activities. All the data were entered and analysed using SPSS version 17. The statistical inference was derived by using chi-square test.

\section{RESULTS}

The results were derived and interpreted by comparing the endemic and non-endemic areas. The sociodemographic comparison between the endemic and nonendemic areas was shown in table 1. It is inferred from the table that in both the areas the age wise distribution was almost similar, whereas the sex wise distribution had shown that the females were more in the CR puthur (nonendemic area) village than the Rajakkamangalam (endemic area) village. People with higher education were found to be more in numbers in the Rajakkamangalm village and also many of the patients reported there were Christians. Majority of the patients from both the villages were belonging to upper lower class based on B G Prasad classification.

The awareness regarding malaria was tested based on certain basic questions regarding malaria. Majority of the study subjects from the endemic area gave a correct response to the questions related to the disease terminology, modes of transmission and the usefulness of indoor residual sprays than the subjects from the nonendemic area and the difference was found to be statistically significant $(\mathrm{P}<.05)($ Table 2$)$. 
Table 1: Comparison of socio-demographic profile of study subjects.

\begin{tabular}{|c|c|c|c|c|c|c|c|}
\hline \multirow{2}{*}{ Variables } & \multicolumn{3}{|c|}{$\begin{array}{l}\text { Rajakkamangalam }(\mathrm{n}=150) \\
\text { (Endemic area) }\end{array}$} & \multicolumn{2}{|c|}{$\begin{array}{l}\text { CR Puthur (n=150) } \\
\text { (Non-endemic area) }\end{array}$} & \multicolumn{2}{|c|}{ Total $(n=300)$} \\
\hline & Category & Frequency & $\%$ & Frequency & $\%$ & Frequency & $\%$ \\
\hline \multirow{4}{*}{ Age distribution } & $<20$ & 13 & 8.7 & 21 & 14.0 & 34 & 11.3 \\
\hline & $21-40$ & 84 & 56.0 & 102 & 68.0 & 186 & 62.0 \\
\hline & $>40$ & 53 & 35.3 & 27 & 18.0 & 80 & 26.7 \\
\hline & Total & 150 & 100.0 & 150 & 100.0 & 300 & 100.0 \\
\hline \multirow{3}{*}{ Sex distribution } & Male & 74 & 49.3 & 56 & 37.3 & 130 & 43.3 \\
\hline & Female & 76 & 50.7 & 94 & 62.7 & 170 & 56.7 \\
\hline & Total & 150 & 100.0 & 150 & 100.0 & 300 & 100.0 \\
\hline \multirow{8}{*}{ Education } & Illiterate & 0 & 0.0 & 1 & 0.7 & 1 & 0.3 \\
\hline & Primary School & 8 & 5.3 & 7 & 4.7 & 15 & 5.0 \\
\hline & Middle School & 25 & 16.7 & 65 & 43.3 & 90 & 30.0 \\
\hline & $\begin{array}{l}\text { High School } \\
\text { Certificate }\end{array}$ & 72 & 48.0 & 51 & 34.0 & 123 & 41.0 \\
\hline & $\begin{array}{l}\text { Post High School } \\
\text { Diploma }\end{array}$ & 32 & 21.3 & 8 & 5.3 & 40 & 13.3 \\
\hline & Graduate & 13 & 8.7 & 16 & 10.7 & 29 & 9.7 \\
\hline & $\begin{array}{l}\text { Profession/ } \\
\text { Honors }\end{array}$ & 0 & 0.0 & 2 & 1.3 & 2 & 0.7 \\
\hline & Total & 150 & 100.0 & 150 & 100.0 & 300 & 100.0 \\
\hline \multirow{4}{*}{ Religion } & Christian & 97 & 64.7 & 68 & 45.3 & 112 & 37.3 \\
\hline & Hindu & 44 & 29.3 & 74 & 49.3 & 171 & 57.0 \\
\hline & Muslim & 9 & 6.0 & 8 & 5.3 & 17 & 5.7 \\
\hline & Total & 150 & 100.0 & 150 & 100.0 & 300 & 100.0 \\
\hline \multirow{4}{*}{$\begin{array}{l}\text { Socio- economic } \\
\text { status }\end{array}$} & Lower Middle & 56 & 37.3 & 60 & 40.0 & 116 & 38.7 \\
\hline & Upper Lower & 79 & 52.7 & 77 & 51.3 & 156 & 52.0 \\
\hline & BPL & 15 & 10.0 & 13 & 8.7 & 28 & 9.3 \\
\hline & Total & 150 & 100.0 & 150 & 100.0 & 300 & 100.0 \\
\hline
\end{tabular}

Table 2: Comparison of malaria awareness between endemic and non endemic areas.

\begin{tabular}{|c|c|c|c|c|c|c|c|c|}
\hline \multirow{2}{*}{$\begin{array}{l}\text { Awareness } \\
\text { about }\end{array}$} & \multirow[t]{2}{*}{ Category } & \multicolumn{2}{|c|}{ Rajakkamangalam } & \multicolumn{2}{|c|}{ CR. Puthur (n=150) } & \multicolumn{2}{|c|}{ Total $(n=300)$} & \multirow{2}{*}{$\begin{array}{l}\text { P value (Chi- } \\
\text { square test) }\end{array}$} \\
\hline & & Frequency & $\%$ & Frequency & $\%$ & Frequency & $\%$ & \\
\hline \multirow{3}{*}{$\begin{array}{l}\text { Disease } \\
\text { Terminology }\end{array}$} & Yes & 137 & 91.3 & 101 & 67.3 & 238 & 79.3 & \multirow[t]{3}{*}{$<.001$} \\
\hline & No & 13 & 8.7 & 49 & 32.7 & 62 & 20.7 & \\
\hline & Total & 150 & 100.0 & 150 & 100.0 & 300 & 100.0 & \\
\hline \multirow{3}{*}{$\begin{array}{l}\text { Malaria } \\
\text { symptoms }\end{array}$} & Yes & 106 & 70.7 & 101 & 67.3 & 207 & 69.0 & \multirow[t]{3}{*}{0.289} \\
\hline & No & 44 & 29.3 & 49 & 32.7 & 93 & 31.0 & \\
\hline & Total & 150 & 100.0 & 150 & 100.0 & 300 & 100.0 & \\
\hline \multirow{3}{*}{$\begin{array}{l}\text { Mode of } \\
\text { transmission }\end{array}$} & Yes & 123 & 82.0 & 99 & 66.0 & 222 & 74.0 & \multirow[t]{3}{*}{$<.001$} \\
\hline & No & 27 & 18.0 & 51 & 34.0 & 78 & 26.0 & \\
\hline & Total & 150 & 100.0 & 150 & 100.0 & 300 & 100.0 & \\
\hline \multirow[t]{3}{*}{ Causative agent } & Yes & 25 & 16.7 & 18 & 12.0 & 43 & 14.3 & \multirow[t]{3}{*}{0.0927} \\
\hline & No & 125 & 83.3 & 132 & 88.0 & 257 & 85.7 & \\
\hline & Total & 150 & 100.0 & 150 & 100.0 & 300 & 100.0 & \\
\hline \multirow{3}{*}{$\begin{array}{l}\text { Blood Smear } \\
\text { examination }\end{array}$} & Yes & 125 & 83.3 & 105 & 70.0 & 230 & 76.7 & \multirow[t]{3}{*}{0.0712} \\
\hline & No & 25 & 16.7 & 45 & 30.0 & 70 & 23.3 & \\
\hline & Total & 150 & 100.0 & 150 & 100.0 & 300 & 100.0 & \\
\hline \multirow{3}{*}{$\begin{array}{l}\text { Indoor } \\
\text { Residual } \\
\text { spays }\end{array}$} & Yes & 119 & 79.3 & 67 & 44.7 & 186 & 62.0 & \multirow[t]{3}{*}{$<.0001$} \\
\hline & No & 31 & 20.7 & 83 & 55.3 & 114 & 38.0 & \\
\hline & Total & 150 & 100.0 & 150 & 100.0 & 300 & 100.0 & \\
\hline
\end{tabular}


Table 3: Comparison of source of health information regarding malaria.

\begin{tabular}{|c|c|c|c|c|c|c|c|}
\hline \multirow[t]{2}{*}{ Communication } & \multicolumn{2}{|c|}{ Rajakkamangalam } & \multicolumn{2}{|c|}{ CR. Puthur } & \multicolumn{2}{|c|}{ Total $(n=300)$} & \multirow{2}{*}{$\begin{array}{l}\text { Pvalue (Chi- } \\
\text { square test) }\end{array}$} \\
\hline & Frequency & $\%$ & Frequency & $\%$ & Frequency & $\%$ & \\
\hline Health workers & 67 & 44.7 & 31 & 20.7 & 98 & 32.6 & $<.0001$ \\
\hline Medical camp & 52 & 34.7 & 56 & 37.3 & 108 & 36.0 & 0.518 \\
\hline A-V Aids & 18 & 12.0 & 14 & 9.3 & 32 & 10.7 & 0.671 \\
\hline Not aware & 13 & 8.6 & 49 & 32.7 & 62 & 20.7 & $<.0001$ \\
\hline Total & 150 & 100 & 150 & 100 & 300 & 100.0 & \\
\hline
\end{tabular}

The source of health information regarding malaria was acquired by the health workers among majority of the study subjects from the endemic area and many of them from the non-endemic areas were not aware about any information regarding malaria and this difference was found to be statistically significant (Table 3).

Table 4: Comparison of health seeking behaviour of the study subjects.

\begin{tabular}{|c|c|c|c|c|c|c|c|c|}
\hline \multirow[b]{2}{*}{ Category } & & \multicolumn{2}{|c|}{ Rajakkamangalam } & \multicolumn{2}{|c|}{ CR. Puthur } & \multicolumn{2}{|c|}{ Total $(n=300)$} & \multirow{2}{*}{$\begin{array}{l}\text { P value } \\
\text { (Chi- } \\
\text { square } \\
\text { test) }\end{array}$} \\
\hline & & Frequency & $\%$ & Frequency & $\%$ & Frequency & $\%$ & \\
\hline \multirow{4}{*}{$\begin{array}{l}\text { Day of initial } \\
\text { visit to the } \\
\text { health centre } \\
\text { after the onset } \\
\text { of fever }\end{array}$} & $\leq 3$ & 100 & 66.7 & 55 & 36.7 & 155 & 51.7 & \multirow{3}{*}{$<.0001$} \\
\hline & 3 to 5 & 29 & 19.3 & 48 & 32.0 & 77 & 25.7 & \\
\hline & $\geq 5$ & 21 & 14.0 & 47 & 31.3 & 68 & 22.7 & \\
\hline & Total & 150 & 100 & 150 & 100 & 300 & 100 & \\
\hline \multirow{3}{*}{$\begin{array}{l}\text { Blood Smear } \\
\text { Examination }\end{array}$} & Done & 124 & 82.7 & 83 & 55.3 & 207 & 69.0 & \multirow{2}{*}{$<.001$} \\
\hline & Not done & 26 & 17.3 & 67 & 44.7 & 93 & 31.0 & \\
\hline & Total & 150 & 100.0 & 150 & 100.0 & 300 & 100.0 & \\
\hline \multirow{4}{*}{$\begin{array}{l}\text { Place of } \\
\text { treatment }\end{array}$} & PHC & 109 & 72.7 & 75 & 50 & 184 & 61.3 & \multirow{3}{*}{$<.001$} \\
\hline & $\begin{array}{l}\text { Govt. } \\
\text { Hospital }\end{array}$ & 16 & 10.7 & 12 & 8 & 28 & 9.3 & \\
\hline & Private & 25 & 16.6 & 63 & 42 & 88 & 14 & \\
\hline & Total & 150 & 100 & 150 & 100 & 300 & 100 & \\
\hline
\end{tabular}

Table 5: Comparison preventive measures adopted by the study subjects.

\begin{tabular}{|c|c|c|c|c|c|c|c|c|}
\hline \multirow{2}{*}{ Category } & & \multicolumn{2}{|c|}{ Rajakkamangalam } & \multicolumn{2}{|c|}{ CR. Puthur } & \multicolumn{2}{|c|}{ Total $(n=300)$} & \multirow{2}{*}{ P value } \\
\hline & & Frequency & $\%$ & Frequency & $\%$ & Frequency & $\%$ & \\
\hline \multirow{3}{*}{$\begin{array}{l}\text { Adoption of any } \\
\text { preventive method }\end{array}$} & Yes & 144 & 96.0 & 142 & 94.6 & 286 & 95.3 & \multirow[t]{3}{*}{0.819} \\
\hline & None & 6 & 4.0 & 8 & 5.3 & 14 & 4.7 & \\
\hline & Total & 150 & 100.0 & 150 & 100.0 & 300 & 100.0 & \\
\hline \multirow{3}{*}{$\begin{array}{l}\text { Carried out Indoor } \\
\text { Residual Spray }\end{array}$} & Yes & 119 & 79.3 & 0 & 0.0 & 119 & 39.7 & \multirow[t]{3}{*}{$<.0001$} \\
\hline & No & 31 & 20.7 & 150 & 100.0 & 181 & 60.3 & \\
\hline & Total & 150 & 100.0 & 150 & 100.0 & 300 & 100.0 & \\
\hline
\end{tabular}

Among the health seeking behaviour majority of the study subjects from the endemic area visits the health centre in less than 3 days after the onset of fever and also undergo a blood smear examination than that of the patients from the non-endemic area and the difference was found to be statistically significant. Most of the patients from a non-endemic area opted for private hospital for their treatment whereas majority of them from the endemic area received the treatment from a government hospital and the difference was found to be statistically significant (Table 4).

The preventive measures related to malaria were followed by both the subjects from the endemic and non-endemic areas but the indoor residual spray was done only in the houses of the people from the endemic area (Table 5). 


\section{DISCUSSION}

The study population included 300 fever cases who presented themselves in the outpatient department of endemic Primary Health Centre, Rajakkamangalam and a non-endemic primary health center Chembagaramanputhur at Kanyakumari district of Tamilnadu state. In this study $62 \%$ belonged to the age group 21-40 years. Most of the population (52.7\% from endemic area and $51.3 \%$ from endemic area) belonged to upper lower socioeconomic scale as per modified B.G. Prasad's socioeconomic classification. According to the religion the endemic area was dominated by Christians $(64.7 \%)$ and the non-endemic area was dominated by Hindus $(57 \%)$. The similarity in the housing pattern and water supply system in both the areas denoted the existence of malariogenic potential in both the areas. The similar type of socio-demographic profile was also quoted in the studies done by Das et al and Omalbanin etal. $^{11,12}$

As for awareness of malaria, majority of the respondents from the endemic area were more aware about the symptoms, mode of transmission and the diagnostic test for malaria when compared to the respondents from nonendemic area. Many studies have shown that respondents have an idea about 2-3 symptoms of malaria. ${ }^{13,15}$ Three most common symptoms enumerated by patients in our study were fever, chills and body-ache.

In the present study $82.7 \%$ and $55.3 \%$ of the study subjects underwent peripheral blood smear from endemic area Rajakkamangalam and non-endemic area Chembagaramanputhur respectively and the results were found to be in contrast to the study conducted by Jian WeiXu et al. ${ }^{16}$ The remarkably reduced practice of blood smear examination which was considered as the gold standard for malaria diagnosis should be given more emphasis in the non-endemic area as there was every possibility of missing out malaria positive cases in these areas.

The role of Health care workers in creating awareness in endemic and non-endemic areas were only $44.7 \%$ and $20.7 \%$ respectively that was in contrast to the study conducted by Alexander et al., in rural Ghana where the health care workers were the main source of awareness $(83.3 \%)$ among the study population followed by the media. ${ }^{17}$ The awareness creation by the health care workers should be emphasized and more attention should also be given in non-endemic areas also.

With regard to the treatment seeking behavior $66.7 \%$ of the respondents from Rajakkamangalam and $36.7 \%$ of the respondents from CR Pudur visited any one of the health care centre within 3 day's period of onset of fever and it is almost in par with the results of other studies ${ }^{18-20}$

In our study more than $90 \%$ of the respondents told that they follow one or more personal prophylactic measure against malaria which was found to be much high than the study done by Ongore D et al where he had quoted that only $51 \%$ of them were practicing the personal prophylactic measures against malaria. ${ }^{13}$

\section{CONCLUSION}

This study highlighted the differences in the level of awareness, health seeking behavior and adoption of personal prophylactic measures with respect to malaria between endemic and non-endemic areas of Nagercoil. The lack of awareness of malaria in non-endemic areas need special attention and the need of health awareness through the health care workers should be enhanced in both the areas. Despite being aware of the government programmes and measures for the control of malaria, nearly one fourth of the population have not received the regular indoor residual insecticide spraying, which highlights the need for strengthening the national programmes.

Funding: No funding sources

Conflict of interest: None declared

Ethical approval: The study was approved by the Institutional Ethics Committee

\section{REFERENCES}

1. WHO/RMB/UNICEF. World Malaria Report 2005. Geneva: World Health Organization. Accessed on 10/4/2016.

2. Govere J, Durrheim D, Grange KL, Mabuza A, Booman M. Community knowledge and perception about malaria and practices influencing malaria control in Mpumalanga province South Africa. South African Med J. 2000;90:611-6.

3. Farid MA. The malaria program from euphoria to anarchy. World Health Forum. 1980;1(1):28-33.

4. Oaks SC, Mitchell VS, Pearson GW, Carpenters CP. Social and behavioural aspects of malaria. In: Oaks SC et al Editors. Malaria: Obstacles and Opportunities. Washington DC: National Academy Press; 1991;257-71.

5. Tanner M, Vlassoff C. Treatment seeking behaviour for malaria: A typology based on endemicity and gender. Social Science and Medicine. 1998;46(45):523-32.

6. Agyepong IA. Malaria: ethno-medical perceptions and practice in Adangbe farming community and implications for control. Social Science and Medicine. 1992;35(2):131-7.

7. Helitzer-Allen DL, Machero A, Wirima J, Kendall C. Testing strategies to increase use of Chloroquine chemoprophylaxis during pregnancy in Malawi. Acta Tropica. 1994;58:255-66.

8. Hlongwana KW, Mabaso MLH, Kunene D, Govender S, Maharaj R. Community knowledge, attitudes and practices (KAP) on malaria in Swaziland: a country earmarked for malaria elimination. Malaria Journal. 2009;8(1):29. 
9. La Cruz ND, Crookston B, Dearden K.Who sleeps under bednets in Ghana? A doer/non-doer analysis of malaria prevention behaviours. Malaria Journal. 2006;5(61).

10. Hughes CM , Mc Bray JC, Reming GF. Benefits and risks of self-medication. Drug safety. 2001;24:1027-37.

11. Das A, Sundari TK, Raveendran. Factors affecting treatment seeking for febrile illness in Boudh district of Orissa. Malaria Journal. 2012;11:41-7.

12. Atashbahar O, Bahrami MA, Asqari R, Fallahzadeh H. An examination of treatment seeking behavior affecting factors: a qualitative study in Iran. World Applied Sciences Journal. 2013;25(5):774-81.

13. Ongore D, Kamunvi F, Knight R, Minawa A. Study of knowledge, attitude and practice (KAP) of a rural community on malaria and the mosquito vector. East African Med J. 1989;66(2):79-89.

14. Singh TG, Singh RKN, Singh EY. A study of knowledge about malaria and treatment seeking behaviour in two tribal communities of Manipur. Indian J Pub Hlth. 2003;47(2):61-5.

15. Rasania SK, Bhanot A, Sachdev TR. Awareness and practices regarding malaria of catchment population of a primary health center in Delhi. J Com Dis. 2002;34(1):78-84.

16. Jain Wei $\mathrm{Xu}, \mathrm{Qu}$ Zhang $\mathrm{Xu}$ and Yi-Rou Zeng. Malaria treatment-seeking behaviour and related factors of Wa ethnic minority in Myanmar: a crosssectional study. Malaria Journal. 2012;11:417.

17. Laar AS, Laar AK, Dalinjong PA. Community perception of malaria and its influence on healthseeking behaviour in rural Ghana: a descriptive study. Malaria World Journal. 2013;4(1):1-4.

18. Govere J, Durrheim D, Grange, Mabuza A, Booman M. Community knowledge and perception about malaria and practices influencing malaria control in Mpumalanga province South Africa. South African Med J. 2000;90:611-6.

19. Vundule C, Mhara Kurula S. Knowledge, practices and perception about malaria in rural communities of Zimbabwe: relevance to malaria control. Bull WHO. 1996;74(1):55-60.

20. Singh TG, Singh RKN, Singh EY. A study of knowledge about malaria and treatment seeking behaviour in two tribal communities of Manipur. Indian J Pub Hlth 2003;47(2):61-5.

Cite this article as: Kumaraswamy USB, Manohar M, Muthukrishnan G, Jebamony K, Radhakrishnan S.

Awareness and treatment seeking behaviour of malaria in selected endemic and non-endemic rural areas of Kanyakumari district, Tamilnadu, India. Int J

Community Med Public Health 2016;3:2313-8. 